\title{
Effect of Sodium Starch Glycolate on Formulation of Fexofenadine Hydrochloride Immediate Release Tablets by Direct Compression Method
}

\author{
S. Karim, A. Bosu, A. Biswas, F. R. Laboni, A. S. Julie, M. H. O. Rashid" \\ Department of Pharmacy, World University of Bangladesh, 151/8, Green Road, Dhaka-1205, \\ Bangladesh
}

Received 29 May 2017, accepted in final revised form 6 October 2017

\begin{abstract}
Present study aspires at the design of an immediate release formulation with prospective use of fexofenadine hydrochloride by exploring the effect of sodium starch glycolate as super disintegrant. Fexofenadine hydrochloride immediate release tablets (Formulations F1, F-2, F-3, F-4 and F-5) using different ratios of sodium starch glycolate as a disintegrant were prepared by direct compression method. Standard physicochemical tests were performed for all the formulations. Dissolution studies of the formulations were done in phosphate buffer, pH 6.8 using USP apparatus II (paddle apparatus) at $50 \mathrm{rpm}$. Percent release of fexofenadine hydrochloride of formulations F-1, F-2, F-3, F-4 and F-5 were $89.98 \%, 90.98 \%, 92.95,96.92 \%$ and $99.85 \%$, respectively after $1 \mathrm{~h}$ and the release pattern followed the zero order kinetics. The release rate in the formulation F-5 was higher compared to other formulations and the studied market products. Sodium starch glycolate speed up the release of the drug from the core tablets, and the release of fexofenadine hydrochloride from tablets was directly proportional to the amount of sodium starch glycolate present in the formulations and there by produced immediate action.
\end{abstract}

Keywords: Fexofenadine hydrochloride; Immediate release; Sodium starch glycolate.

(C) 2018 JSR Publications. ISSN: 2070-0237 (Print); 2070-0245 (Online). All rights reserved. doi: http://dx.doi.org/10.3329/jsr.v10i1.32703 J. Sci. Res. 10 (1), 31-38 (2018)

\section{Introduction}

The oral drug delivery is the most widely used route of administration among the routes for treatment of pathological conditions. Different techniques are used to release active drug from core tablets, coated tablets and coated beads, granules and microsphere, multi tablet system and encapsulated drug etc. Immediate release of drug from core tablet is the most suitable technique for quick action. Tablet is the most popular among all the dosage forms existing today because of its convenience of self administration, compactness and

\footnotetext{
Corresponding author: rashid4@pharmacy.wub.edu.bd
} 
easy manufacturing; however in many cases immediate onset of action is required than conventional therapy. To overcome the drawbacks of extended release tablet, immediate release dosage form has emerged as alternative oral dosage forms [1]. The concept of immediate release tablets emerged from the desire to provide patient with more conventional means of taking their medication when emergency treatment is required. Most of the technologies for the manufacture of immediate release tablets use super disintegrant so that the tablet disintegrates rapidly [2]. Recently immediate release tablets have started gaining popularity and accepted as a drug delivery system, because they are easy to administer, showed quick onset of action, economical and lead to better patient compliance. Therefore, immediate release tablet is a tool for expanding markets, extending product life cycles and generating opportunities for the products $[3,4]$.

Fexofenadine hydrochloride is a second-generation non-sedative $\mathrm{H}_{1}$ receptor antagonist widely used in seasonal allergic rhinitis. Blockage of $\mathrm{H}_{1}$ receptor prevents the activation of the histamine receptor, preventing the symptoms associated with allergies. Fexofenadine has elimination half life $14.4 \mathrm{~h}$ and pharmacokinetics are linear for oral doses (60/120 mg twice daily) and $60 \%$ to $70 \%$ bound to plasma proteins, primarily albumin and $\alpha$ 1-acid glycoprotein [5]. Approximately, 5\% of the total dose of fexofenadine hydrochloride was eliminated by hepatic metabolism. As it is included in class III of the Biopharmaceutical Classification System (BCS), the use of super disintegrating agent might be necessary to improve the absorption, thereby increasing the bioavailability [6,7].

In the studies to improve dosage form design, we reported the effects of different polymer ethyl cellulose, HPMC-K15, kollidon $\mathrm{Cl}$ on the release of active drugs from matrix tablets [8,9]; and different super disintegrant such as sodium starch glycolate and kollidon $\mathrm{Cl}$ on immediate release of loratadine from tablets [1]. The tablet formulations containing sodium starch glycolate were found to release loratadine rapidly compared to formulations containing kollidon $\mathrm{Cl}$. Sodium starch glycolate attracts water molecule rapidly to swell the tablets and disintegrate quickly as well as dissolve and facilitate the absorption of medicament from gastrointestinal tract. Therefore, we have used sodium starch glycolate in various concentrations in direct compression of fexofenadine hydrochloride tablet and thereby focused the effect on the release of fexofenadine hydrochloride from the tablets.

\section{Experimental}

\subsection{Materials}

Fexofenadine hydrochloride (Vashudha Pharm Chemical Ltd, Telangana, India; purity 99.33\%) was obtained as a gift sample from Square Pharmaceuticals Ltd, Bangladesh. Sodium starch glycolate was obtained from ACI Pharmaceuticals Ltd, Bangladesh. Lactose, povidone K-30 and talcum powder were purchased from local market. Three brands of fexofenadine tablets (P-1, P-2 and P-3) were obtained from well known 
Bangladeshi Pharmaceuticals such as Square Pharmaceuticals Ltd, ACME Laboratories Ltd and Beximco Pharmaceuticals Ltd, respectively. The other necessary ingredients were the highest grade obtained from the available commercial sources.

\subsection{Pre-formulation studies of powder blends}

The pre-formulation studies like bulk density, tapped density, angle of repose, compressibility index and hausner's ratio were performed for different ingredients according to reported method [10].

\subsection{Preparation of fexofenadine hydrochloride tablets}

Fexofenadine hydrochloride immediate release tablets using sodium starch glycolate as super disintegrant were prepared by direct compression method. All the ingredients including active drug, super disintegrant and excipients were weighed accurately according to the formulation code (Table 1) and then sieved to get uniform particle size. The active ingredient and other excipients except lubricants were mixed for $10 \mathrm{~min}$. Lubricants were added after uniform mixing and again mixed for $5 \mathrm{~min}$. After proper mixing, the appropriate amounts of granules were compressed with $2.0-2.5$ ton pressure for each tablet using a laboratory hydraulic press (KBR Press; model No: M-16, India) and dice set.

Table 1. Formulation of fexofenadine hydrochloride immediate release tablets.

\begin{tabular}{llllllll}
\hline $\begin{array}{l}\text { Formulation } \\
\text { code }\end{array}$ & $\begin{array}{l}\text { API } \\
(\mathrm{mg})\end{array}$ & $\begin{array}{l}\text { Sodium } \\
\text { starch } \\
\text { glycolate } \\
(\mathrm{mg})\end{array}$ & $\begin{array}{l}\text { \% of Sodium } \\
\text { starch } \\
\text { glycolate }\end{array}$ & $\begin{array}{l}\text { Lactose } \\
(\mathrm{mg})\end{array}$ & $\begin{array}{l}\text { Povidone } \\
\text { K-30 } \\
(\mathrm{mg})\end{array}$ & $\begin{array}{l}\text { Talc } \\
(\mathrm{mg})\end{array}$ & $\begin{array}{l}\text { Total } \\
\text { Weight } \\
(\mathrm{mg})\end{array}$ \\
\hline F-1 & 120 & 35 & $(14.0 \%)$ & 67 & 18 & 10 & 250 \\
F-2 & 120 & 45 & $(18.0 \%)$ & 57 & 18 & 10 & 250 \\
F-3 & 120 & 55 & $(22.0 \%)$ & 47 & 18 & 10 & 250 \\
F-4 & 120 & 65 & $(26.0 \%)$ & 37 & 18 & 10 & 250 \\
F-5 & 120 & 75 & $(30.0 \%)$ & 27 & 18 & 10 & 250 \\
\hline
\end{tabular}

\subsection{Evaluation of compressed tablets}

The compressed tablets were characterized by their physical properties. The physical appearance, average weight, friability, thickness and diameter were determined for 20 tablets of each formulation $[8,11]$.

\subsubsection{In-vitro disintegration time}

The disintegration time for all formulations and commercial products (P-1 to P-3) was measured using a tablet disintegration test apparatus (Model, KI - 2249). The water was 
maintained at a temperature of $37 \pm 1^{\circ} \mathrm{C}$ and the time taken for the entire tablet to disintegrate completely was noted (Table 2 ).

\subsubsection{Determination of $\lambda_{\max }$ and standard calibration curve of fexofenadine hydrochloride}

Standard fexofenadine hydrochloride (working standard) $50 \mathrm{mg}$ was weighed and dissolved in $100 \mathrm{~mL}$ of $50 \mathrm{mM}$ phosphate buffer, $\mathrm{pH} 6.8$ to get a concentration of 500 $\mu \mathrm{g} / \mathrm{mL}$ of standard stock solution. An ultraviolet spectrophotometric scanning (190-400 $\mathrm{nm}$ ) was carried out to justify the $\lambda_{\max }$ in the experimental conditions. Then various concentrations ranged between $0-60 \mu \mathrm{g} / \mathrm{mL}$ was prepared from stock solution by serial dilution technique. A calibration curve $\left(\mathrm{y}=0.014 \mathrm{x}+0.017, \mathrm{R}^{2}=0.997\right)$ was obtained by plotting the concentration against absorbance which was taken at $\lambda_{\max }(259 \mathrm{~nm})$ using UV spectrophotometer from Shimadzu (Fig. 1).

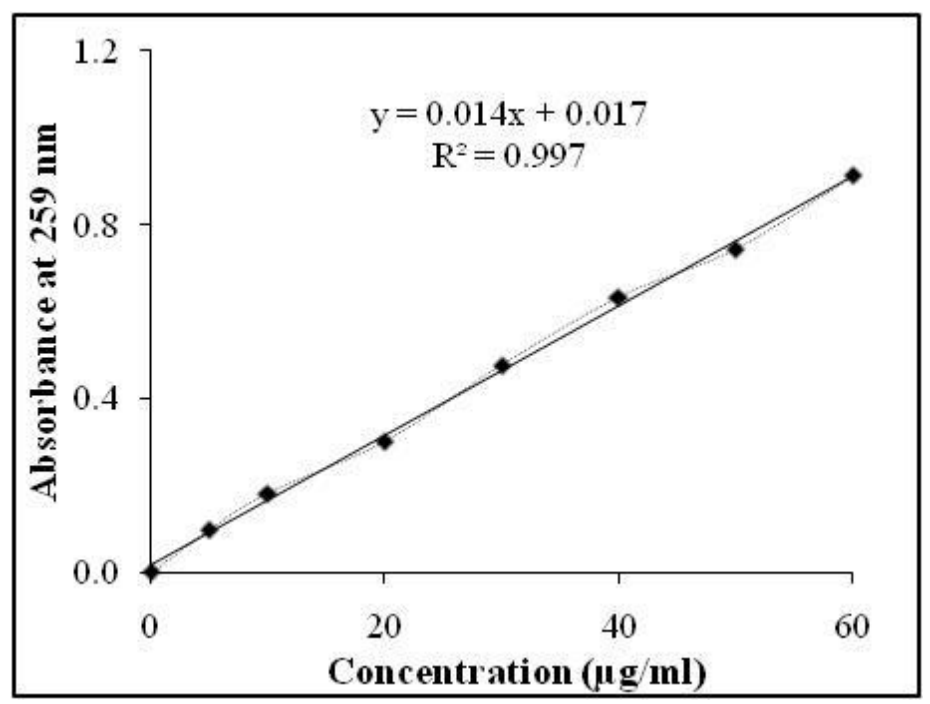

Fig. 1. Standard calibration curve of fexofenadine hydrochloride recorded by UV spectrophotometer at $259 \mathrm{~nm}$.

\subsubsection{Potency determination of the prepared tablets}

Twenty tablets were weighed and crushed into powder. An aliquot of grounded powder was taken, dissolved and diluted to suitable volume with $50 \mathrm{mM}$ phosphate buffer, $\mathrm{pH}$ 6.8. The potency of each formulation was estimated by using UV-spectrophotometer at 259 $\mathrm{nm}$ and calculated by standard calibration curve of fexofenadine hydrochloride $(\mathrm{y}=$ $\left.0.014 \mathrm{x}+0.017, \mathrm{R}^{2}=0.997\right)$. 


\subsubsection{Dissolution Studies}

Dissolution tests of fexofenadine hydrochloride tablets were conducted according to the USP method (USP XXII) using apparatus II (Model RC 100A). In all cases the conditions were maintained to be exactly the same, i.e. the rpm was maintained at 50, while the temperature was maintained at $37 \pm 0.5^{\circ} \mathrm{C}$ in $900 \mathrm{~mL}$ phosphate buffer of $\mathrm{pH} 6.8$ as dissolution media [12]. The dissolution was carried out for $1 \mathrm{~h}$ in triplicate basket. The test sample $(5 \mathrm{~mL})$ was collected at particular time interval and replaced with fresh dissolution medium maintained at the same temperature. After proper dilution of collected sample, the concentration of dissolved drug was assayed at $259 \mathrm{~nm}$ using UV spectrophotometer. The percent of drug release from core tablets was analyzed by fitting to zero order [9] model equation (percentage drug release against time) using standard calibration curve $\left(\mathrm{y}=0.014 \mathrm{x}+0.017, \mathrm{R}^{2}=0.997\right)$.

\section{Results and Discussion}

\subsection{Evaluation of powder blends}

Flow properties of different ingredients are shown in Table 2 . The bulk density and tapped density for different ingredients varied from $(0.561-0.662) \mathrm{g} / \mathrm{mL}$ and $(0.671-0.767) \mathrm{g} /$ $\mathrm{mL}$ respectively. Using these two densities data, compressibility index and hausner's ratio were calculated. The percent compressibility lies within the range of (13.68-16.39)\% and hausner's ratio is in the range of (1.15-1.19) for different ingredients. Different ingredients showed the angle of repose within $30^{\circ}$. However, the outcomes of these parameters indicated good flow properties for different ingredients and suitable for compression.

Table 2. Evaluation of powder flow properties of different ingredients.

\begin{tabular}{|c|c|c|c|c|c|c|}
\hline Ingredients & & $\begin{array}{l}\text { Bulk } \\
\text { density } \\
(\mathrm{gm} / \mathrm{mLl})\end{array}$ & $\begin{array}{l}\text { Tapped } \\
\text { density } \\
(\mathrm{gm} / \mathrm{mL})\end{array}$ & $\begin{array}{l}\text { Carr's } \\
\text { index } \\
(\%)\end{array}$ & $\begin{array}{l}\text { Hausner's } \\
\text { ratio }\end{array}$ & $\begin{array}{l}\text { Angle of } \\
\text { repose } \\
\left({ }^{\circ} \mathrm{C}\right)\end{array}$ \\
\hline $\begin{array}{l}\text { Sodium } \\
\text { glycolate }\end{array}$ & starch & 0.662 & 0.767 & 13.68 & 1.15 & 22 \\
\hline Lactose & & 0.600 & 0.700 & 14.28 & 1.16 & 21 \\
\hline Talc & & 0.561 & 0.671 & 16.39 & 1.19 & 24 \\
\hline
\end{tabular}

\subsection{Physical parameters}

The prepared tablets were preliminary analyzed for evaluating physical properties such as weight, hardness, thickness, diameter, and friability. The results are summarized in Table 3. The average weight of the tablets was found uniform and standardized at approximately $250 \mathrm{mg}$. The average diameter was found to be much consistent $(8.01 \mathrm{~mm})$. The average thicknesses were ranges between $2.36-2.38 \mathrm{~mm}$ and uniformity in the values indicates that formulations were compressed without sticking to the dice and punches. The friability of 
the tablets of different formulations varied greatly ranging from 0.112 to $0.231 \%$. According to some authentic references the maximum friability range should not be more than $0.4 \%$ [13]. Hardness of the tablets of the different formulations varied widely from $2.36 \pm 0.009$ to $2.93 \pm 0.011 \mathrm{Kg} / \mathrm{cm}^{2}(\mathrm{n}=20)$ and these values indicated that the hardness of all the formulations possessed good mechanical strength with sufficient hardness.

\subsection{Disintegration time and potency}

Disintegration time is very important for immediate release tablets as the internal structure of tablets (pore size distribution, water penetration capability and swelling of disintegrating substance) suggested the mechanism of disintegration. Disintegration time of formulated tablets was within the range. The formulations F-4 and F-5 showed disintegration time less than $45 \mathrm{sec}$ and potency was calculated to be about $100 \pm 0.50 \%$ (Table 3).

Table 3. Comparison of various parameters and potency of formulated (F-1 to F-5) and market (p-1 to P-3) preparations of fexofenadine tablets.

\begin{tabular}{l|l|l|l|l|l|l|l}
\hline $\begin{array}{l}\text { Product } \\
\text { Code }\end{array}$ & $\begin{array}{l}\text { Average } \\
\text { weight } \\
(\mathrm{g})\end{array}$ & $\begin{array}{l}\text { Diameter } \\
(\mathrm{mm})\end{array}$ & $\begin{array}{l}\text { Thickness } \\
(\mathrm{mm})\end{array}$ & $\begin{array}{l}\text { Friability } \\
(\%)\end{array}$ & $\begin{array}{l}\text { Hardness } \\
\left(\mathrm{kg} / \mathrm{cm}^{2}\right)\end{array}$ & $\begin{array}{l}\text { Disintegration } \\
\text { time }(\mathrm{sec})\end{array}$ & $\begin{array}{l}\text { *Potency } \\
(\%)\end{array}$ \\
\hline F-1 & $250 \pm 0.5$ & $8.01 \pm 0.01$ & $2.36 \pm 0.01$ & 0.112 & $3.5 \pm 0.01$ & $70 \pm 6$ & 99.7 \\
F-2 & $250 \pm 0.4$ & $8.01 \pm 0.01$ & $2.36 \pm 0.01$ & 0.167 & $3.0 \pm 0.01$ & $64 \pm 5$ & 99.5 \\
F-3 & $250 \pm 0.5$ & $8.01 \pm 0.01$ & $2.38 \pm 0.12$ & 0.231 & $2.6 \pm 0.01$ & $50 \pm 7$ & 100.3 \\
F-4 & $250 \pm 0.7$ & $8.01 \pm 0.01$ & $2.38 \pm 0.12$ & 0.144 & $2.9 \pm 0.01$ & $45 \pm 5$ & 99.8 \\
F-5 & $250 \pm 0.4$ & $8.01 \pm 0.01$ & $2.38 \pm 0.12$ & 0.112 & $3.0 \pm 0.01$ & $38 \pm 3$ & 100.2 \\
\hline P-1 & $293 \pm 3.0$ & & & & $6.0 \pm 0.50$ & $58 \pm 7$ & 99.9 \\
P-2 & $310 \pm 5.0$ & & & & $6.5 \pm 0.25$ & $68 \pm 8$ & 100.5 \\
P-3 & $364 \pm 3.0$ & & & & $5.5 \pm 0.50$ & $78 \pm 5$ & 101.5 \\
\hline
\end{tabular}

$(n=20$; Average $\pm S D) ; *$ Each analysis was done in triplicates and taken average results

\subsection{Effect of sodium starch glycolate on drug release}

The in vitro dissolution study was conducted in the USP paddle apparatus in $50 \mathrm{mM}$ phosphate buffer, $\mathrm{pH}$ 6.8. The percent of drug dissolved was observed for $1 \mathrm{~h}$. A drug is said to be released by zero order kinetics when the rate of drug release is independent of the concentration of drug in the tablet. The zero order release profile (percent of drug release versus time) of formulated products is shown in Fig. 2A. The cumulative percentage drug release from formulation F-1, F-2, F-3, F-4 and F-5 were 89.98, 90.98, $92.95,96.92$ and $99.85 \%$, respectively within $1 \mathrm{~h}$. While the market preparations P-1, P-2 and P-3 showed percentage of drug release as 95.85, 92.69 and 94.69\%, respectively, which are comparatively lower than formulation F-4 and F-5 (Fig. 2B). The dissolution data by zero order model revealed that maximum drug was released after $1 \mathrm{~h}$ from the formulation F-5 (99.85\%) while the formulation F-1 released only $89.98 \%$. Thus F-5 showing a more immediate release than other formulations and high dissolution may occur due to faster breakdown. At low concentration of sodium starch glycolate, the 
release of drug was generally seen to be lower, while at the high concentration of sodium starch glycolate, the release of drug showed proportional higher values. The disintegration time, potency and dissolution characteristics of formulated tablets were also compared with that of available market preparations (Table 3 and Fig. 2). The disintegration time of prepared fexofenadine tablet was significantly lower than that of market preparations and hence improves the dissolution properties.

A

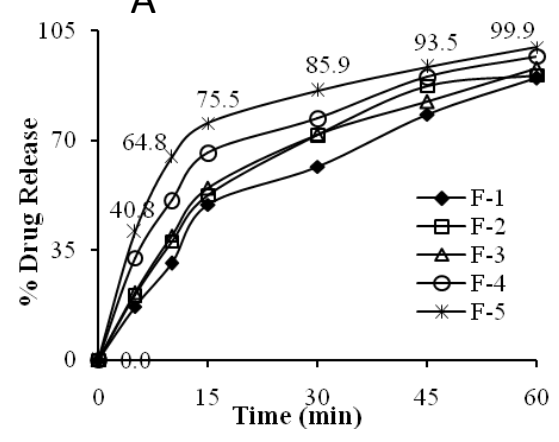

B

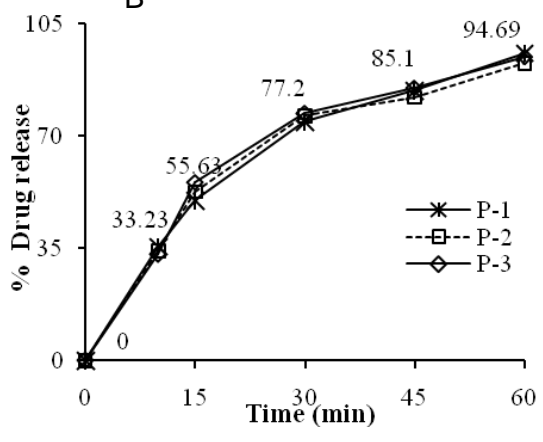

Fig. 2. Zero order release profile of fexofenadine hydrochloride from core tablets. A, Laboratory formulations having different ratio of sodium starch glycolate; B, Various commercially available preparations from market.

\section{Conclusion}

In-vitro release studies demonstrated that the release of fexofenadine hydrochloride from all the tablet formulations were generally immediate due to the use of different ratios of sodium starch glycolate as super disintegrant in the formulation. From the study of release profiles of formulation F-5 containing 30\% sodium starch glycolate was superior as compared to other formulations. The release uniqueness was significantly influenced by the characteristics and concentration of the sodium starch. The release rate was increased with the increase of sodium starch glycolate as well as increased the dissolution properties and hence the immediate action will be obtained by formulation F-5 compared to the studied commercial products (P-1, P-2 and P-3).

\section{References}

1. S. Karim, S. Islam, K. Jahan, M. H. Ali, K. N. Deepa, and M. Shahriar, Int. J. Pharmacy 7, 79 (2017). https://www.researchgate.net/publication/316473440

2. U. R. Bagmar, P. S. Jadhav, A. M. Lunkad, S. G. Uttarwar, and S. S. Jangam, Am. J. Pharmat. Res. 3, 635 (2013).

3. D. Douroumis, Expert Opinion on Drug Delivery 4, 417 (2007). http://dx.doi.org/10.1517/17425247.4.4.417

4. Y. Katsuragi, Y. Sugiura, C. Lee, K. Otsuji, and K. Kurihara, Pharm. Res. 12, 658 (1995). https://doi.org/10.1023/A:1016295122461 
5. K. Vidyadhari, P. Sirisha, V. Deepthi, and B. D. Devi, World J. Pharm. Pharmaceut. Sci. 5, 2022 (2016). http://doi.org/10.20959/wjpps20166-7043

6. C. Leuner and J. Dressman, Eur. J. Pharm. Biopharm. 50, 47 (2000). https://doi.org/10.1016/S0939-6411(00)00076-X

7. S. Muranishi, Pharm. Res. 2, 108 (1985). https://doi.org/10.1023/A:1016307231798

8. S. Karim, F. Hossain, J. Uddin, M. A. Bhuyan, and M. H. O. Rashid, World J. Sci. Eng. 1, 39 (2016). https://www.researchgate.net/publication/305439961

9. S. Karim, M. A. Bhuiyan, and M. S. Rana, Bang. Pharm. J. 18, 157 (2015). https://www.researchgate.net/publication/280577794

10. M. P. Wagh, C. P. Yewale, S. U. Zate, P. I. Kothawade, and G. H. Mahale, Int. J. Pharm. Pharma. Sci. 2, 155 (2010). http://ijppsjournal.com/Vol2Suppl1.htm

11. United State Pharmacopoeia (United States Pharmacopoeial Convention, Rockville, Maryland, 2007).

12. S. Akbar, R. Bhatta, M. A. Rahman, M. S. Hossain, and M. G. Uddin, J. Sci. Res. 9, 247 (2017). http://dx.doi.org/10.3329/jsr.v9i2.30600.

13. A. Ashnagar, M. Kouchak, M. Soltani, and A. Salimi, J. Chem. 4, 563 (2007). http://dx.doi.org/10.1155/2007/835754 